\title{
FAKTOR-FAKTOR YANG BERHUBUNGAN DENGAN KEJADIAN LESI PRAKANKER SERVIKS DI PUSKESMAS PADANG PASIR KOTA PADANG
}

\author{
FACTORS THAT ARE RELATED TO THE INCIDENCE OF \\ CERVICAL PRECANCEROUS LESIONS IN PADANG PASIR \\ PUBLIC HEALTH CENTER IN PADANG CITY
}

\author{
Lisa Rahmawati, Mahdalena Prihatin Ningsih \\ Prodi DIII Kebidanan Padang Poltekkes Kemenkes Padang \\ Korespondensi: lisarahmawati2406@gmail.com
}

\begin{abstract}
Cervical cancer is the second leading cause of cancer death in women in developing countries, including Indonesia. Precancerous cervical lesions are changes in the cell nucleus before becoming the cancer cell nucleus. Precancerous cervical lesions can develop into cancer if not detected early. Women who did early detection of cervical cancer with the method of Visual Acetate Acid Inspection in Padang Pasir Public Health Center in 2017 were 656 persons and 1.225 persons 2018. The purpose of this study was to determine the factors related to the incidence of cervical precancerous lesions in Padang Pasir Public Health Center in Padang City. This research is an analytic survey with case control design. The study was conducted from 28 December in 2019 to 11 January in 2020. The population is all women who did an IVA examinations at Padang Pasir Public Health Center in 2018. In the case group there were 56 samples taken by simple random sampling and in the control group there were 56 samples taken by systematic random sampling. Data were analysed by univariate and bivariate by chi square test. The results showed that there was a relationship between early sexual activity with cervical precancerous lesions $(p=0.023$, OR $=2.583)$, no relationship between smoking with cervical precancerous lesions $(p=0.438)$, a relationship of parity with cervical precancerous lesions $(p=0.002$ OR $=3.587)$, no relationship between family history of cervical cancer with cervical precancerous lesions $(p=0.124)$, and there is a relationship of age with precancerous cervical lesions $(p=0.000$ OR $=7.222)$. In conclusion there is a relationship between early sexual activity, parity, and age with cervical precancerous lesions, there is no relationship between smoking and family history of cervical cancer with cervical precancerous lesions. Therefore, midwives are expected to reduce the incidence of early sexual activity, risk parity and age at risk by increasing health promotion.
\end{abstract}

Keywords : Precancerous cervical lesions, early sexual activity, smoking, parity, family history of cervical cancer, age

\begin{abstract}
ABSTRAK
Kanker serviks merupakan penyebab kematian kedua kanker pada wanita di negara negara berkembang termasuk Indonesia. Lesi prakanker serviks adalah perubahan inti sel sebelum menjadi inti sel kanker. Lesi prakanker serviks dapat berkembang menjadi kanker bila tidak dideteksi lebih awal. Wanita yang melakukan deteksi dini kanker
\end{abstract}


serviks dengan metode Inspeksi Visual Asam Asetat (IVA) di Puskesmas Padang Pasir pada tahun 2017 sebanyak 656 orang dan 1.225 orang pada tahun 2018. Tujuan dari penelitian ini adalah untuk mengetahui Faktor-Faktor yang Berhubungan dengan Kejadian Lesi Prakanker Serviks di Puskesmas Padang Pasir. Jenis penelitian ini adalah survey analitik dengan desain kasus kontrol. Penelitian dilakukan pada tanggal 28 Desember 2019 sampai 11 Januari 2020. Populasi adalah seluruh wanita yang melakukan pemeriksaan IVA di Puskesmas Padang Pasir Kota Padang tahun 2018. Pada kelompok kasus terdapat 56 sampel yang diambil secara simple random sampling dan pada kelompok kontrol terdapat 56 sampel yang diambil secara systematic random sampling. Data dianalisis secara univariat dan bivariat dengan uji chi square. Hasil penelitian didapatkan ada hubungan aktifitas seksual dini dengan lesi prakanker serviks ( $p=0,023, \mathrm{OR}=2,583)$, tidak ada hubungan merokok dengan kejadian lesi prakanker serviks $(p=0,438)$, ada hubungan paritas dengan kejadian lesi prakanker serviks $(p=0,002, \mathrm{OR}=3,587)$, tidak ada hubungan riwayat kanker serviks pada keluarga dengan kejadian lesi prakanker serviks $(p=0,124)$, dan ada hubungan usia dengan kejadian lesi prakanker serviks $(p=0,000, \mathrm{OR}=7,222)$. Kesimpulan penelitian ada hubungan aktifitas seksual dini, paritas dan usia dengan kejadian lesi prakanker serviks dan tidak ada hubungan merokok dan riwayat kanker serviks pada keluarga dengan kejadian lesi prakanker serviks. Peneliti berharap peranan petugas kesehatan khususnya bidan dapat mengurangi angka kejadian aktifitas seksual dini dan jumlah paritas berisiko dengan melakukan promosi kesehatan secara personal maupun kelompok.

Kata Kunci : Lesi prakanker serviks, aktifitas seksual dini, merokok, paritas, riwayat ca serviks, usia

\section{PENDAHULUAN}

World Health Organization (WHO) tahun 2011 mengatakan bahwa kanker leher rahim atau kanker serviks adalah salah satu masalah kesehatan terkemuka yang mencolok bagi perempuan di seluruh dunia dengan perkiraan 529.409 kasus baru dan sekitar 89 persen di negara-negara berkembang. Kanker serviks menempati urutan kedua dari semua jenis kanker pada wanita di Indonesia. Menurut data Globocan, prevalensi kanker serviks di Indonesia menunjukkan adanya peningkatan dari 15 per 100.000 penduduk di tahun 2008 menjadi 23,4 per 100.000 penduduk pada tahun 2018.

Sebelum terjadinya kanker serviks, akan didahului dengan keadaan yang disebut lesi prakanker atau Cervical Intraepithelial Neoplasia (CIN). Lesi prakanker adalah kelainan sel serviks berupa perubahan inti sel sebelum inti sel menjadi inti sel kanker. Sekitar $15 \%$ displasia ringan akan berkembang menjadi displasia sedang, sekitar 30\% displasia sedang akan berkembang menjadi displasia berat dan sekitar $40 \%$ mengalami regresi menjadi displasia ringan. Sekitar $45 \%$ displasia berat akan berkembang menjadi 
karsinoma insitu dan sekitar 20\% mengalami regresi menjadi displasia sedang. Semua kasus karsinoma insitu akan berkembang menjadi karsinoma mikroinvasif kemudian invasif. Dari penelitian histokimia sulit membedakan pada tingkat mana displasia menjadi irreversible. Antara displasia berat dan karsinoma insitu tidak ada perbedaan secara bermakna baik histopatologi dan sitologi sehingga displasia berat dan karsinoma insitu dimasukkan dalam kelompok yang sama yaitu CIN III.

Pada stadium displasia, masih dapat dilakukan upaya pencegahan agar tidak terjadi kanker invasif. Upaya ini dapat dilakukan dengan cara pap smear dan menggunakan metode Inspeksi Visual Asam Asetat (IVA). Pemeriksaan IVA merupakan pemeriksaan skrining alternatif dari pap smear karena biaya murah, praktis, sangat mudah dilaksanakan dan peralatan sederhana serta dapat dilakukan oleh tenaga kesehatan selain dokter ginekologi.

Berdasarkan Profil Kesehatan Indonesia tahun 2018 cakupan pemeriksaan tes IVA di Provinsi Sumatera Barat tahun 2018 adalah 18,89\%. Cakupan pemeriksaan IVA tertinggi di Sumatera Barat tahun 2017 adalah Kota Padang. Berdasarkan data cakupan deteksi dini kanker leher rahim dengan metode IVA dan kanker payudara dengan pemeriksaan klinis (SADANIS) di Puskesmas se-Kota Padang yang diselenggarakan tahun 2018, dari 23 Puskesmas yang ada di Kota Padang, pemeriksaan IVA positif terbanyak terdapat di Puskesmas Padang Pasir dimana dari 1.225 orang wanita yang diperiksa, sebanyak 110 orang diantaranya terdeteksi IVA positif.

Beberapa penelitian terdahulu melaporkan bahwa selain infeksi HPV, terdapat beberapa faktor lain yang berpengaruh terhadap kejadian lesi prakanker yang merupakan cikal bakal kanker serviks yaitu usia pertama kali berhubungan seksual kurang dari 20 tahun dan merokok. Penelitian yang dilakukan oleh Nindrea berjudul Prevalensi dan Faktor yang Mempengaruhi Lesi Prakanker Serviks Pada Wanita di RS Dr. Mohammad Hoesin Palembang pada tahun 2016 menunjukkan adanya hubungan usia pertama kali berhubungan seksual kurang dari 20 tahun dan merokok dengan kejadian lesi prakanker serviks.

Selain aktivitas seksual terlalu dini dan merokok, jumlah paritas yang 
tinggi dan usia juga menyumbang angka kejadian lesi prakanker serviks. Penelitian yang dilakukan oleh Wahyuningsih berjudul Faktor Risiko Terjadinya Lesi Prakanker Serviks Melalui Deteksi Dini dengan Metode IVA Puskesmas Kecamatan Jatinegara Tahun 2013 menunjukkan adanya hubungan paritas $>3$ dan usia dengan kejadian lesi prakanker serviks. Faktor risiko terakhir yaitu riwayat kanker serviks pada keluarga. Penelitian yang dilakukan oleh Nifa berjudul FaktorFaktor yang Berhubungan dengan Kejadian IVA Positif pada Wanita Berusia 30-50 Tahun di Kabupaten Sukoharjo Tahun 2016 menunjukkan adanya hubungan riwayat kanker serviks pada keluarga dengan kejadian lesi prakanker serviks.

Berdasarkan studi pendahuluan yang dilakukan peneliti dengan melihat data rekam medis terhadap 10 orang ibu dengan hasil pemeriksaan IVA positif di Puskesmas Padang Pasir Kota Padang. Didapatkan 3 ibu dengan usia pertama kali berhubungan seksual $<20$ tahun, 2 ibu dengan merokok, 4 ibu dengan jumlah paritas $>3,2$ ibu dengan riwayat kanker serviks pada keluarga dan 7 ibu dengan usia $\geq 35$ tahun.
Berdasarkan tingginya kejadian lesi prakanker di Puskesmas Padang Pasir Kota Padang, serta banyak sumber yang mengatakan bahwa aktifitas seksual dini, merokok, jumlah paritas, riwayat kanker serviks pada keluarga dan usia memiliki pengaruh terhadap lesi prakanker serviks. Hal ini membuat peneliti tertarik untuk melakukan penelitian tentang faktor-faktor yang berhubungan dengan kejadian lesi prakanker serviks di Puskesmas Padang Pasir Kota Padang.

\section{METODE}

Jenis penelitian yang digunakan yaitu survey analitik dengan desain kasus kontrol dengan pendekatan retrospektif. Populasi dalam penelitian ini adalah seluruh wanita yang melakukan deteksi dini kanker serviks dengan metode IVA di Puskesmas Padang Pasir. Jumlah sampel dalam penelitian ini berjumlah 56 orang untuk sampel kasus dan 56 orang untuk sampel kontrol. Teknik pengambilan sampel dengan menggunakan teknik simple random sampling. Data dikumpulkan menggunakan format pengumpulan data. Pengolahan data secara univariat dan bivariat menggunakan chi-square. 
HASIL DAN PEMBAHASAN

\section{Analisis Univariat}

Tabel 1 Distribusi Frekuensi Usia Pertama Kali Berhubungan Seksual Pada Kelompok Kasus dan Kelompok Kontrol di Puskesmas Padang Pasir Kota Padang

\begin{tabular}{ccccc}
\hline Usia Pertama & \multicolumn{2}{c}{ Kasus } & \multicolumn{2}{c}{ Kontrol } \\
\cline { 2 - 5 } $\begin{array}{c}\text { Kali } \\
\text { Berhubungan } \\
\text { Seksual }\end{array}$ & $\mathbf{f}$ & & $\mathbf{f}$ & $\mathbf{\%}$ \\
\hline Tidak Patuh & 33 & 58,9 & 20 & 35,7 \\
Patuh & 23 & 41,1 & 36 & 64,3 \\
\hline Jumlah & 56 & 100 & 56 & 100 \\
\hline
\end{tabular}

Berdasarkan tabel 1 diketahui bahwa terdapat 33 responden $(58,9 \%)$ dengan usia pertama kali berhubungan seksual <20 tahun pada kelompok kasus, sedangkan pada kelompok kontrol terdapat 20 responden $(35,7 \%)$ yang usia pertama kali berhubungan seksual $<20$ tahun.

Tabel 2 Distribusi Frekuensi Merokok Pada Kelompok Kasus dan Kelompok Kontrol di Puskesmas Padang Pasir Kota Padang

\begin{tabular}{ccccc}
\hline \multirow{2}{*}{ Merokok } & \multicolumn{2}{c}{ Kasus } & \multicolumn{2}{c}{ Kontrol } \\
\cline { 2 - 5 } & f & \% & f & \% \\
\hline Merokok & 5 & 8,9 & 2 & 3,6 \\
Tidak & 51 & 91,1 & 54 & 96,4 \\
Merokok & & & & \\
\hline Jumlah & 56 & 100 & 56 & 100 \\
\hline
\end{tabular}

Berdasarkan tabel 2 diketahui bahwa terdapat 5 responden $(8,9 \%)$ yang merokok pada kelompok kasus, sedangkan pada kelompok control terdapat 2 responden $(3,6 \%)$ yang merokok.

Tabel 3 Distribusi Frekuensi Jumlah Paritas Pada Kelompok Kasus dan Kelompok Kontrol di Puskesmas Padang Pasir Kota Padang

\begin{tabular}{ccccc}
\hline \multirow{2}{*}{ Paritas } & \multicolumn{2}{c}{ Kasus } & \multicolumn{2}{c}{ Kontrol } \\
\cline { 2 - 5 } & f & \% & f & \% \\
\hline > 3 orang anak & 33 & 58,9 & 16 & 28,6 \\
$\leq 3$ orang anak & 23 & 41,1 & 40 & 71,4 \\
\hline Jumlah & 56 & 100 & 56 & 100 \\
\hline
\end{tabular}

Berdasarkan tabel 3 diketahui bahwa terdapat 33 responden $(58,9 \%)$ yang memiliki paritas $>3$ orang anak pada kelompok kasus, sedangkan pada kelompok kontrol terdapat 16 responden $(28,6 \%)$ yang memiliki paritas $>3$ orang anak.

Tabel 4 Distribusi Frekuensi Riwayat Kanker Serviks Pada Keluarga Kelompok Kasus dan Kelompok Kontrol di Puskesmas Padang Pasir Kota Padang

\begin{tabular}{ccccc}
\hline Riwayat & \multicolumn{2}{c}{ Kasus } & \multicolumn{2}{c}{ Kontrol } \\
\cline { 2 - 5 } $\begin{array}{c}\text { kanker } \\
\text { serviks pada } \\
\text { keluarga }\end{array}$ & $\mathbf{f}$ & $\boldsymbol{\%}$ & $\mathbf{f}$ & $\mathbf{\%}$ \\
\hline $\begin{array}{c}\text { Ada } \\
\text { Tidak Ada }\end{array}$ & 9 & 16,1 & 3 & 5,4 \\
\hline Jumlah & 56 & 83,9 & 53 & 94,6 \\
\hline
\end{tabular}

Berdasarkan tabel 4 diketahui bahwa terdapat 9 responden $(16,1 \%)$ yang memiliki keluarga dengan riwayat kanker serviks pada kelompok kasus, sedangkan pada kelompok kontrol 
terdapat 3 responden $(5,4 \%)$ yang memiliki keluarga dengan riwayat kanker serviks.

Tabel 5 Distribusi Frekuensi Usia Pada Kelompok Kasus dan Kelompok Kontrol di Puskesmas Padang Pasir Kota Padang

\begin{tabular}{ccccc}
\hline \multirow{2}{*}{ Usia } & \multicolumn{2}{c}{ Kasus } & \multicolumn{2}{c}{ Kontrol } \\
\cline { 2 - 5 } & f & \% & f & \% \\
\hline$\geq 35$ tahun & 50 & 89,3 & 30 & 5,4 \\
$<35$ tahun & 6 & 10,7 & 26 & 46,4 \\
\hline Jumlah & 56 & 100 & 56 & 100 \\
\hline
\end{tabular}

Berdasarkan tabel 5 diketahui bahwa terdapat 50 responden $(89,3 \%)$ dengan usia $\geq 35$ tahun pada kelompok kasus, sedangkan pada kelompok control terdapat 30 responden $(53,6 \%)$ dengan usia $\geq 35$ tahun.

Tabel 6 Hubungan Usia Pertama Kali Berhubungan Seksual dengan Kejadian Lesi Prakanker Serviks di Puskesmas Padang Pasir Kota Padang

\begin{tabular}{|c|c|c|c|c|c|c|c|c|}
\hline \multirow{2}{*}{$\begin{array}{c}\text { Usia Pertama } \\
\text { Kali } \\
\text { Berhubungan } \\
\text { Seksual }\end{array}$} & \multicolumn{2}{|c|}{ Kasus } & \multicolumn{2}{|c|}{ Kontrol } & \multicolumn{2}{|c|}{ Total } & \multirow{2}{*}{$\begin{array}{c}\mathbf{P} \\
\text { value }\end{array}$} & \multirow{2}{*}{$\begin{array}{c}\text { OR } \\
\text { (CI } \\
95 \%)\end{array}$} \\
\hline & $\mathbf{f}$ & $\%$ & f & $\%$ & $\mathbf{f}$ & $\%$ & & \\
\hline$<20$ tahun & 33 & 58,9 & 20 & 35,7 & 53 & 47,3 & \multirow[b]{2}{*}{0,023} & \multirow[b]{2}{*}{2,583} \\
\hline$\geq 20$ tahun & 23 & 41,1 & 36 & 64,3 & 59 & 52,7 & & \\
\hline Jumlah & 56 & 100 & 56 & 100 & 112 & 100 & & \\
\hline
\end{tabular}

Berdasarkan Tabel 6 diketahui bahwa dari 56 responden yang mengalami lesi prakanker serviks terdapat 33 responden $(58,9 \%)$ yang melakukan hubungan seksual pertama kali usia <20 tahun, lebih besar dibandingkan dengan responden yang tidak mengalami lesi prakanker serviks sebanyak 20 responden $(35,7 \%)$. Berdasarkan hasil uji statistik didapatkan $p$ value $=0,023$ maka dapat disimpulkan ada hubungan usia pertama kali berhubungan seksual dengan kejadian lesi prakanker serviks. Nilai OR yang didapatkan dari analisis adalah 2,583, artinya ibu yang melakukan hubungan seksual pertama kali $<20$ tahun memiliki risiko 2,583 mengalami lesi prakanker serviks dibandingkan ibu yang melakukan hubungan seksual pertama kali $\geq 20$ tahun.

Penelitian ini sejalan dengan penelitian Chairani di Rumah Sakit Umum Daerah dr Pirngadi Medan tahun 2017 yang menyatakan adanya hubungan aktifitas seksual dini dengan kejadian lesi prakanker serviks dengan nilai $p$ 0,002 dan OR 3,359. Penelitian ini juga sebanding dengan penelitian yang dilakukan oleh Lestariningsih di RSUD Abdul Moeloek Bandar Lampung tahun 2016 yang menyatakan adanya hubungan aktifitas seksual dini dengan kejadian lesi prakanker serviks dengan nilai $p$ 0,000 dan OR 20, 350.

Wanita yang terlalu dini melakukan hubungan seksual mempunyai risiko yang besar untuk 
mengalami kanker serviks. Hal ini dikaitkan dengan pembentukan sel atau lapisan dinding vagina dan serviks yang belum matang sempurna, disebabkan oleh ketidakseimbangan hormonal.

Ukuran kematangan bergantung pada sel-sel mukosa yang terdapat di selaput kulit bagian dalam rongga tubuh. Umumnya sel mukosa baru matang setelah wanita berusia diatas 20 tahun. Oleh karena itu, hubungan seksual yang dilakukan di bawah usia 20 tahun memungkinkan terjadinya perlukaan pada serviks. Luka yang ditimbulkan menjadi media yang mudah untuk mengalami infeksi, termasuk infeksi dari virus HPV yang menyebabkan kanker serviks.

Berdasarkan hasil penelitian yang telah dilakukan peneliti di Puskesmas Padang Pasir Kota Padang menunjukkan bahwa adanya hubungan yang bermakna antara usia pertama kali berhubungan seksual dengan kejadian lesi prakanker serviks. Hasil penelitian ini sama dengan teori yang mengatakan hubungan seksual yang dilakukan pada usia kurang dari 20 tahun menyebabkan lesi prakanker serviks.

Menurut asumsi peneliti, sebagian besar responden berdomisili di Purus, dimana daerah tepi pantai dengan keadaan ekonomi menengah kebawah. Wanita yang memiliki ekonomi menengah kebawah cenderung lebih banyak menderita lesi prakanker serviks dibandingkan wanita dengan ekonomi menengah keatas. Hal ini disebabkan oleh rendahnya pengetahuan wanita tersebut tentang kanker serviks. Pengetahuan yang rendah dapat diakibatkan oleh rendahnya tingkat pendidikan seorang wanita. Akibat pendidikan rendah inilah wanita cenderung menikah lebih muda sehingga mereka melakukan hubungan seksual dibawah usia 20 tahun, namun tidak menutup kemungkinan terjadinya hubungan seksual pertama kali diluar nikah. Jadi, aktifitas seksual dini inilah yang meningkatkan risiko kejadian lesi prakanker serviks.

Tabel 7 Hubungan Merokok dengan Kejadian Lesi Prakanker Serviks di Puskesmas Padang Pasir Kota Padang

\begin{tabular}{|c|c|c|c|c|c|c|c|c|}
\hline \multirow{2}{*}{ Merokok } & \multicolumn{2}{|c|}{ Kasus } & \multicolumn{2}{|c|}{ Kontrol } & \multicolumn{2}{|c|}{ Total } & \multirow{2}{*}{$\begin{array}{c}P \\
\text { value }\end{array}$} & \multirow{2}{*}{$\begin{array}{c}\text { OR } \\
(\mathrm{CI} \\
95 \%)\end{array}$} \\
\hline & f & $\%$ & f & $\%$ & f & $\%$ & & \\
\hline $\mathrm{Ya}$ & 5 & 8,9 & 2 & 3,6 & 7 & 6,2 & & \\
\hline Tidak & 51 & 91,1 & 54 & 96,4 & 105 & 93,8 & & \\
\hline Jumlah & 56 & 100 & 56 & 100 & 112 & 100 & & \\
\hline
\end{tabular}

Berdasarkan tabel 7 diketahui bahwa dari 56 responden yang mengalami lesi prakanker serviks 
terdapat 5 responden $(8,9 \%)$ yang merokok, lebih besar dibandingkan dengan responden yang tidak mengalami lesi prakanker serviks sebanyak 2 responden $(3,6 \%)$. Hasil uji statistik diperoleh nilai $p=0,438$ maka dapat disimpulkan tidak ada hubungan merokok dengan kejadian lesi prakanker serviks.

Penelitian ini sejalan dengan penelitian Wahyuningsih di Puskesmas Kecamatan Jatinegara tahun 2013 yang menyatakan tidak adanya hubungan merokok dengan kejadian lesi prakanker serviks dengan nilai $p$ 0,252. Namun, penelitian ini tidak sejalan dengan penelitian Nindrea di RS dr Mohammad Hosein Palembang tahun 2016 yang menyatakan adanya hubungan merokok dengan kejadian lesi prakanker serviks dengan nilai $p 0,032$.

Wanita yang merokok memiliki kemungkinan dua kali lipat terkena kanker serviks dibandingkan yang tidak merokok. Risiko meningkat dengan peningkatan jumlah konsumsi batang rokok. Rokok terbuat dari daun tembakau yang mengandung bahan karsinogen. Asapnya mengandung sekitar 4000 jenis senyawa yang sebagian merupakan bahan karsinogenik.
Zat-zat karsinogen yang dihasilkan dari rokok sering ditemukan pada serviks wanita yang aktif merokok dan menjadi kokarsinogen infeksi HPV, dengan kata lain merokok dapat akan meningkatkan risiko terkena lesi prakanker serviks. Hasil penelitian yang telah dilakukan peneliti menunjukkan bahwa $71 \%$ responden yang merokok menderita lesi prakanker serviks. Responden yang merokok mempunyai peluang 2,647 kali lebih besar untuk mengalami lesi prakanker serviks dibandingkan dengan responden yang tidak merokok. Namun hasil statistik menunjukkan bahwa tidak ada hubungan yang signifikan antara kebiasaan merokok dengan kejadian lesi prakanker serviks.

Berdasarkan hasil penelitian yang telah dilakukan peneliti di Puskesmas Padang Pasir Kota Padang menunjukkan bahwa tidak adanya hubungan yang bermakna antara merokok dengan kejadian lesi prakanker serviks. Menurut asumsi peneliti, jumlah angka perokok wanita di Indonesia tergolong masih sangat sedikit, begitupula jumlah perokok pada ibu-ibu yang melakukan pemeriksaan IVA di Puskesmas Padang Pasir Kota Padang, dimana didapatkan hasil hanya 
sebagian kecil ibu yang merokok pada kelompok kasus dan kelompok kontrol. Hal ini yang membuat belum cukup bukti untuk menyatakan ada hubungan antara kejadian lesi prakanker serviks dengan kebiasaan merokok.

Tabel 8 Hubungan Jumlah Paritas dengan Kejadian Lesi Prakanker Serviks di Puskesmas Padang Pasir Kota Padang

\begin{tabular}{|c|c|c|c|c|c|c|c|c|}
\hline \multirow{2}{*}{ Paritas } & \multicolumn{2}{|c|}{ Kasus } & \multicolumn{2}{|c|}{ Kontrol } & \multicolumn{2}{|c|}{ Total } & \multirow{2}{*}{$\begin{array}{c}P \\
\text { value }\end{array}$} & \multirow{2}{*}{$\begin{array}{c}\text { OR } \\
(\mathrm{CI} \\
95 \%)\end{array}$} \\
\hline & f & $\%$ & f & $\%$ & f & $\%$ & & \\
\hline$>3$ orang & 33 & 58,9 & 16 & 28,6 & 49 & 43,8 & & \\
\hline$\leq 3$ orang & 23 & 41,1 & 40 & 71,4 & 63 & 56,2 & 0,002 & 3,587 \\
\hline Jumlah & 56 & 100 & 56 & 100 & 112 & 100 & & \\
\hline
\end{tabular}

Berdasarkan tabel 8 diketahui bahwa dari 56 responden yang mengalami lesi prakanker serviks terdapat 33 responden $(58,9 \%)$ yang memiliki paritas >3, lebih besar dibandingkan dengan responden yang tidak mengalami lesi prakanker serviks sebanyak 16 responden (28,6\%). Hasil uji statistik diperoleh nilai $p=0,002$ maka dapat disimpulkan ada hubungan jumlah paritas dengan kejadian lesi prakanker serviks. Nilai OR yang didapatkan dari analisis adalah 3,587, artinya ibu yang jumlah paritas $>3$ orang anak memiliki risiko 3,587 mengalami lesi prakanker serviks dibandingkan ibu yang jumlah paritasnya $\leq 3$ orang anak.

Penelitian ini sejalan dengan penelitian Lestariningsih di RSUD Abdul Moeloek Bandar Lampung tahun 2016 yang menyatakan adanya hubungan paritas > 3 orang anak dengan kejadian lesi prakanker serviks dengan nilai $p$ 0,036 dan OR 2,38. Hasil penelitian ini juga sebanding dengan penelitian yang dilakukan oleh Putri di RSUD Arifin Achmad Pekanbaru tahun 2013 yang menyatakan adanya hubungan paritas $>3$ orang anak dengan kejadian lesi prakanker serviks dengan nilai $p$ 0,000 dan OR 3,396.

Paritas atau kelahiran yang paling optimal adalah kelahiran sampai ketiga kali. Semakin banyak proses melahirkan yang dialami oleh seorang ibu, maka semakin tinggi risikonya untuk terkena kanker serviks.

Wanita yang pernah hamil selama 9 bulan sebanyak tiga kali atau lebih berisiko terkena kanker serviks lebih tinggi. Ada beberapa dugaan kondisi ini dipengaruhi oleh perubahan hormonal selama kehamilan yang berpotensi membuat wanita lebih rentan terhadap infeksi HPV. Menurunnya daya tahan tubuh selama kehamilan 
juga memungkinkan adanya infeksi HPV dan pertumbuhan kanker.

Ada beberapa pendapat yang memperlihatkan korelasi antara jumlah paritas dengan kanker serviks. Pertama, saat proses melahirkan, janin tentu saja akan keluar melalui serviks yang merupakan leher rahim, jembatan antara rahim dan vagina. Keluarnya janin akan menimbulkan trauma pada serviks. Jika serviks mengalami kelahiran terus menerus maka serviks juga akan semakin mengalami trauma. Kedua, adanya perubahan hormonal bagi wanita selama kehamilan sehingga membuat wanita tersebut lebih mudah terkena infeksi HPV dan pertumbuhan kanker. Ketiga, adalah pendapat bahwa wanita hamil memiliki imunitas yang lebih rendah sehingga memudahkan masuknya HPV dalam tubuh yang berujung pada pertumbuhan kanker.

Berdasarkan hasil penelitian yang telah dilakukan peneliti di Puskesmas Padang Pasir Kota Padang menunjukkan bahwa adanya hubungan yang bermakna antara jumlah paritas lebih dari 3 dengan kejadian lesi prakanker serviks. Pada penelitian ini peneliti hanya menghitung jumlah paritas pervaginam seluruh responden. Oleh karena itu, semakin sering ibu melahirkan pervaginam maka semakin sering serviks mengalami trauma serta lemahnya imunitas wanita pada saat hamil sehingga mudah untuk terinfeksi HPV.

Tabel 9 Hubungan Riwayat Kanker Serviks Pada Keluarga dengan Kejadian Lesi Prakanker Serviks di Puskesmas Padang Pasir Kota Padang

\begin{tabular}{|c|c|c|c|c|c|c|c|c|}
\hline \multirow{2}{*}{$\begin{array}{c}\text { Riwayat } \\
\text { Kanker } \\
\text { serviks } \\
\text { pada } \\
\text { keluarga }\end{array}$} & \multicolumn{2}{|c|}{ Kasus } & \multicolumn{2}{|c|}{ Kontrol } & \multicolumn{2}{|c|}{ Total } & \multirow{2}{*}{$\begin{array}{c}\mathbf{P} \\
\text { value }\end{array}$} & \multirow{2}{*}{$\begin{array}{c}\text { OR } \\
(\mathrm{CI} \\
95 \%)\end{array}$} \\
\hline & f & $\%$ & f & $\%$ & $\mathbf{f}$ & $\%$ & & \\
\hline Ada & 9 & 16,1 & 3 & 5,4 & 12 & 10,7 & & \\
\hline Tidak ada & 47 & 83,9 & 53 & 94,6 & 100 & 89,3 & 0,124 & 3,383 \\
\hline Jumlah & 56 & 100 & 56 & 100 & 112 & 100 & & \\
\hline
\end{tabular}

Berdasarkan tabel 9 diketahui bahwa dari 56 responden yang mengalami lesi prakanker serviks terdapat 9 responden $(16,1 \%)$ yang memiliki keluarga dengan riwayat kanker serviks, lebih besar dibandingkan dengan responden yang tidak mengalami lesi prakanker serviks sebanyak 3 responden $(5,4 \%)$. Hasil uji statistik diperoleh nilai $p=0,124$ maka dapat disimpulkan tidak ada hubungan riwayat kanker serviks pada keluarga dengan kejadian lesi prakanker serviks.

Penelitian ini sejalan dengan penelitian Fitrisia dkk di Puskesmas wilayah kerja Puskesmas Muara Bungo 1 tahun 2019 yang menyatakan tidak adanya hubungan riwayat kanker 
serviks pada keluarga dengan kejadian lesi prakanker serviks dengan nilai $p$ 0,252 . Namun, penelitian ini tidak sejalan dengan penelitian Aziyah dkk di RSUP dr Kariadi Semarang tahun 2016 yang menyatakan adanya hubungan riwayat kanker serviks pada keluarga dengan kejadian lesi prakanker serviks dengan nilai $p 0,032$.

Kanker dipelajari secara khusus, ilmu yang mempelajari mengenai kanker disebut onkologi. Onkogenesis merupakan perubahan sel-sel normal menjadi abnormal yang dicirikan dengan proliferasi seluler yang tak terkontrol. Sejumlah mutasi onkogenik bisa diwariskan dari keluarga atau diinduksi dari paparan lingkungan yang mengandung bahan karsinogenik. Sekitar 5-10\% kasus kanker merupakan penyakit yang diturunkan.

Apabila seseorang perempuan memiliki riwayat kanker serviks dalam keluarganya (ibu atau saudara perempuan) maka akan meningkatkan risiko terkena kanker serviks dalam keluarganya. Hal ini disebabkan adanya kondisi yang diturunkan secara genetik yang menyebabkan ketidak mampuan melawan HPV.

Banyak faktor risiko kanker serviks yang disebabkan oleh gaya hidup yang salah. Namun, apabila saudara kandung atau ibu mempunyai riwayat kanker serviks, maka risiko seseorang untuk terkena kanker serviks juga lebih besar dibandingkan wanita yang tidak memiliki riwayat keluarga demikian. Beberapa penelitian menduga hal ini berkaitan dengan berkurangnya kemampuan orang tersebut dan keluarganya untuk melawan infeksi HPV.

Berdasarkan hasil penelitian yang telah dilakukan peneliti di Puskesmas Padang Pasir Kota Padang menunjukkan bahwa tidak adanya hubungan yang bermakna antara riwayat kanker serviks pada keluarga dengan kejadian lesi prakanker serviks. Menurut asumsi peneliti, ketidaksesuaian hasil yang ada pada penelitian ini dengan teori yang ada berarti ada faktor risiko lain yang dapat memicu kejadian lesi prakanker serviks seperti usia, jumlah paritas dan aktifitas seksual dini. Hal lain yang juga dapat menyebabkan ketidaksesuaian hasil penelitian dengan teori yang ada adalah ketika seorang wanita yang memiliki riwayat kanker serviks pada keluarga, namun memiliki pola hidup yang sehat seperti tidak merokok, memiliki jumlah paritas yang tidak lebih dari tiga, tidak 
melakakukan aktivitas seksual dini atau tidak memiliki riwayat persalinan pervaginam.

Tabel 10 Hubungan usia dengan Kejadian Lesi Prakanker Serviks di Puskesmas Padang Pasir Kota Padang

\begin{tabular}{|c|c|c|c|c|c|c|c|c|}
\hline \multirow{2}{*}{$\begin{array}{l}\text { Usia Saat } \\
\text { Tes IVA }\end{array}$} & \multicolumn{2}{|c|}{ Kasus } & \multicolumn{2}{|c|}{ Kontrol } & \multicolumn{2}{|c|}{ Total } & \multirow{2}{*}{$\begin{array}{c}\mathbf{P} \\
\text { value }\end{array}$} & \multirow{2}{*}{$\begin{array}{c}\text { OR } \\
(\mathrm{CI} \\
95 \%)\end{array}$} \\
\hline & f & $\%$ & f & $\%$ & f & $\%$ & & \\
\hline$\geq 35$ tahun & 50 & 89,3 & 30 & 53,6 & 80 & 71,4 & & \\
\hline$<35$ tahun & 6 & 10,7 & 26 & 46,4 & 32 & 28,6 & 0,000 & 7,222 \\
\hline Jumlah & 56 & 100 & 56 & 100 & 112 & 100 & & \\
\hline
\end{tabular}

Berdasarkan tabel 10 diketahui bahwa dari 56 responden yang mengalami lesi prakanker serviks terdapat 50 responden $(89,3 \%)$ dengan usia $\geq 35$ tahun, lebih besar dibandingkan dengan responden yang tidak mengalami lesi prakanker serviks sebanyak 30 responden $(53,6 \%)$. Hasil uji statistik diperoleh nilai $p=0,000$ maka dapat disimpulkan ada hubungan usia dengan kejadian lesi prakanker serviks. Nilai OR yang didapatkan dari analisis adalah 7,222, artinya ibu dengan usia $\geq 35$ tahun memiliki risiko 7,222 mengalami lesi prakanker serviks dibandingkan ibu dengan usia $<35$ tahun.

Penelitian ini sejalan dengan penelitian Wahyuningsih di Puskesmas Kecamatan Jatinegara tahun 2013 yang menyatakan adanya hubungan usia $\geq 35$ tahun dengan kejadian lesi prakanker serviks dengan nilai $p$ value 0,001 dan OR 5,826. Penelitian ini juga sebanding dengan penelitian yang dilakukan oleh Fitrisia dkk di Puskesmas wilayah kerja Puskesmas Muara Bungo 1 tahun 2019 yang menyatakan adanya hubungan usia dengan kejadian lesi prakanker serviks dengan nilai $p 0,037$.

Usia merupakan bagian dari status reproduksi yang penting. Usia berkaitan dengan peningkatan atau penurunan fungsi tubuh sehingga mempengaruhi status kesehatan seseorang. Semakin tua usia seorang perempuan maka semakin tinggi risikonya terkena kanker serviks. Perempuan yang mengidap kanker serviks adalah mereka yang berusia 3550 tahun, terutama bagi mereka yang aktif secara seksual. ${ }^{1}$ Hal ini dikarenakan virus HPV perlu waktu antara 10-20 tahun untuk bertransformasi menjadi kanker serviks.

Seiring bertambahnya usia seorang wanita, maka semakin rendah daya tahan tubuh wanita tersebut. Hal ini yang menyebabkan semakin meningkatnya risiko kanker serviks. Proses penuaan tidak dapat dicegah, namun dapat dilakukan upaya-upaya pencegahan risiko kanker serviks. 
Berdasarkan hasil penelitian yang telah dilakukan peneliti di Puskesmas Padang Pasir Kota Padang menunjukkan bahwa adanya hubungan yang bermakna antara usia dengan kejadian lesi prakanker serviks. Hal tersebut sesuai dengan teori yang menyatakan adanya hubungan kanker serviks dengan usia $\geq 35$ tahun. Menurut asumsi peneliti, meningkatnya risiko lesi prakanker serviks pada usia lanjut merupakan gabungan dari meningkatnya dan bertambah lamanya waktu pemaparan terhadap karsinogen serta semakin lemahnya sistem imunitas tubuh sehingga hal ini yang membuat wanita usia lanjut mudah untuk terinfeksi HPV.

\section{SIMPULAN}

Sebanyak 58,9\% ibu dengan aktifitas seksual dini pada kelompok kasus dan $35,7 \%$ ibu dengan aktifitas seksual dini pada kelompok control, 8,9\% ibu merokok pada kelompok kasus dan $3,6 \%$ ibu merokok pada kelompok kontrol, 58,9\% ibu dengan jumlah paritas >3 pada kelompok kasus dan $28,6 \%$ ibu dengan jumlah paritas $>3$ pada kelompok kontrol, 16,1\% ibu dengan riwayat kanker serviks pada keluarga pada kelompok kasus dan
5,4\% ibu dengan riwayat kanker serviks pada keluarga pada kelompok kontrol, $89,3 \%$ ibu dengan usia $\geq 35$ tahun pada kelompok kasus dan 53,6\% ibu dengan usia $\geq 35$ tahun pada kelompok kontrol, ada hubungan usia pertama kali berhubungan seksual dengan kejadian lesi prakanker serviks, tidak ada hubungan merokok dengan kejadian lesi prakanker serviks, ada hubungan jumlah paritas dengan kejadian lesi prakanker serviks, tidak ada hubungan riwayat kanker serviks pada keluarga dengan kejadian lesi prakanker serviks, ada hubungan usia dengan kejadian lesi prakanker serviks.

\section{DAFTAR PUSTAKA}

Ariani, Sofi. Stop Kanker. Yogyakarta : Istana Media; 2015

Dedeh Sri, Rahayu. Asuhan Ibu dengan Kanker Serviks. Jakarta : Salemba Medika; 2015
Kementrian Kesehatan Republik Indonesia. Buletin Jendela Data dan Informasi Kesehatan. [sumber online] 2013 [diakses 02 Oktober 2019]. Tersedia dari : URL: http://www.depkes.go.id

Kementrian Kesehatan Republik Indonesia. Riset Kesehatan Dasar. [sumber online] 2018 [diakses 03 
Oktober 2019]. Tersedia dari : URL: http://www.depkes.go.id

Riksani, Ria. Kenali Kanker Serviks

Sejak Dini. Yogyakarta : Rapha

Publising; 2016

Adekunle. Cervical Intraepithelial

Neoplasia (CIN) Departement of

Obstetric and Gynekologi.

Ahmadu Bello University

Teaching Hospital: Zaria Kaduna

State Nigeria; 2012

Fasiah, SA. Waspada Kanker Serviks.

Jakarta: Lintang Aksara; 2010

Kementrian Kesehatan Republik

Indonesia. Profil Kesehatan

Indonesia 2018. [sumber online]

2018 [diakses 04 Oktober 2019].

Tersedia dari : URL:

http://www.depkes.go.id

Dinas Kesehatan Provinsi Sumatera

Barat. Profil Kesehatan Sumatera

Barat tahun 2017. [sumber online]

2017 [diakses 04 Oktober 2019].

Tersedia dari : URL:

http://www.depkes.go.id

Dinas Kesehatan Kota Padang. Profil

Kesehatan Kota Padang tahun

2018. [sumber online] 2018

[diakses 04 Oktober 2019].

Tersedia dari : URL:

http://www.depkes.go.id
Savitri, Astrid, dkk. Kupas Tuntas Kanker Payudara, Leher Rahim dan Rahim. Yogyakarta : Penerbit Pustaka Baru Press; 2015

Nindrea, Richvan Dana. Prevalensi dan Faktor yang Mempengaruhi Lesi Pra Kanker Serviks Pada Wanita di RS Dr. Mohammad Hoesin. Palembang: Jurnal Endurance Volume 2; 2017. Tersedia pada http://dx.doi.org/10.22216/jen.v2il $\underline{.1538}$

Wahyuningsih, Tri dan Erry Yudhya Mulyani. Faktor Risiko Terjadinya Lesi Prakanker Serviks Melalui Deteksi Dini dengan Metode Iva Puskesmas Kecamatan Jatinegara. Jakarta: Jurnal Forum Ilmiah Volume 11; 2013. Tersedia pada https://digilib.esaunggul.ac.id/boo kmark/1063/YANG

Lestari, Nifa Dian. Faktor-Faktor yang Berhubungan dengan Kejadian IVA Positif pada Wanita Berusia 30-50 Tahun di Kabupaten Sukoharjo. Skripsi Jurusan Ilmu Kesehatan Masyarakat: Universitas Semarang; 2016. Tersedia pada https://lib.unnes.ac.id/28267/ Yarbo, Connie Henke dkk. Cancer Nursing Principles and Practice. 
Library of Congress Cataloging-in

Publication Data : USA; 2011

Nugroho, Taufan. Masalah Kesehatan

Reproduksi Wanita. Yogyakarta :

Nuha Medika; 2014

Prawirohardjo, Sarwono. Ilmu

Kandungan. Jakarta : PT Bina

Pustaka Sarwono Prawirohardjo; 2011

Sinta dkk. Kanker Serviks dan Infeksi

Human Papilloma Virus (HPV).

Jakarta : Javamedia Network;

2010

Purwoastuti, Endang. Panduan Materi

Kesehatan Reproduksi dan

Keluarga Berencana. Yogyakarta :

Pustaka Baru Press; 2014

French, Kathy. Kesehatan Seksual.

Jakarta : Bumi Medika; 2015

Sulistiya Ningsih dkk. Faktor-Faktor yang Berhubungan dengan

Terjadinya Kanker Serviks di

RSUP Dr. Sadjito. Yogyakarta:

Jurnal Berita Kedokteran

Masyarakat Volume 33; 2016.

Tersedia pada

https://journal.ugm.ac.id/bkm/artic

le/download/17160/16357

Lubis, Rhina Chairani. Faktor Risiko yang Memengaruhi Kejadian Kanker Serviks pada Wanita di Rumah Sakit Umum Daerah dr.
Pirngadi Medan [Tesis] 2017

[diakses $07 \quad$ Oktober 2019]

Tersedia dari URL:

http://repositori.usu.ac.id

Andriyani, Ratih. Bahaya Merokok.

Jakarta : Sarana bangun Pustaka;

2011

Stoppard, Miriam. Panduan Kesehatan

Keluarga. Jakarta: Penerbit

Erlangga; 2010

Sukmana, Teddie. 2009. Mengenal

Rokok dan Bahayanya.

[Ebook].[dikutip pada 7 Oktober

2018]. Tersedia pada

https://books.google.co.id/

Lestari, handayani dkk. Menaklukkan Kanker Serviks dan Kanker Payudara dengan 3 Terapi Alami. Jakarta : PT Agro Media Pustaka; 2012

Purwoastuti, Endang. Panduan Materi Kesehatan Reproduksi dan Keluarga Berencana. Yogyakarta : Pustaka Baru Press; 2014

Lestariningsih, Sri dan Martini. FaktorFaktor yang Berhubungan dengan Terjadinya Kanker Serviks di RSUD Abdul Moeloek. Bandar Lampung: Jurnal Kesehatan Metro Sai Wawai Volume 4; 2012. Tersedia pada https://ejurnal.poltekkes- 
tjk.ac.id/index.php/JKM/article/vi ew/708

Darmayanti, Ika Putri. Faktor - Faktor yang Berhubungan dengan Kejadian Kanker Serviks RSUD Arifin Achmad. Pekanbaru: Jurnal Kesehatan Komunitas Volume 2; 2013. Tersedia pada http://jurnal.htp.ac.id/index.php/ke skom/article/download/51/40

Friedman, M. Buku Ajar Keperawatan Keluarga. Jakarta: EGC; 2010

Team Cancer Help. Stop Kanker. Jakarta : PT. Agro Media Pustaka; 2010

Aziyah dkk. Faktor Risiko yang Berhubungan dengan Kejadian Kanker Serviks di RSUP Dr. Kariadi. Semarang: Jurnal Riset Kesehatan Volume 6; 2016. Tersedia pada http://ejournal.poltekkessmg.ac.id/ojs/index.php/jrk/article/ view/2085

Wiknjosastro, Hanifa. Ilmu Kebidanan. Jakarta: YBP-SP; 2010

Marmi. Kesehatan Reproduksi. Yogyakarta: Pustaka Pelajar; 2015 Darmawan, Deni. Metode Penelitian Kuantitatif. Bandung : PT Remaja Rosdakarya; 2016
Dahlan, Sopiyudin. Besar Sampel dalam Penelitian Kedokteran dan Kesehatan. Jakarta: Epidemiologi Indonesia; 2016

Notoatmodjo, Soekidjo. Metodologi Penelitian Kesehatan. Jakarta : PT. Rineka Cipta; 2012

Dahlan, Sopiyudin. Statistik Untuk Kedokteran dan Kesehatan. Jakarta: Epidemiologi Indonesia; 2014

Fitrisia dkk. Analisis Faktor-Faktor yang Berhubungan dengan Kejadian Lesi Prakanker Serviks pada Wanita Pasangan Usia Subur di Wilayah Kerja Puskesmas Muara Bungo 1. Tersedia pada http://jurnal.fk.unand.ac.id 